\title{
Short- and Mid-term Effects of Acute Coronary Syndromes on Smoking Behaviour, Factors Affecting Smoking Status and the Family Physicians' Role After Discharge
}

\author{
Akut Koroner Sendromların Sigara İçme Davranışları Üzerine Kısa ve Orta Vadeli \\ Etkileri, Taburculuk Sonrası Sigara İçme Durumunu Etkileyen Faktörler ve Aile \\ Hekimlerinin Rolü
}

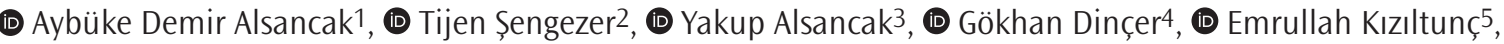 \\ (1) Adem Özkara6
}

\begin{abstract}
${ }^{1}$ Ministry of Health, Konya Provincial Health Directorate, Konya, Turkey
2University of Health Sciences Turkey, Ankara Keçiören Training and Research Hospital, Clinic of Family Medicine, Ankara, Turkey

${ }^{3}$ Necmettin Erbakan University Meram Faculty of Medicine, Department of Cardiology, Konya, Turkey

${ }^{4}$ Konya Selçuklu Number 39 Family Health Center, Konya, Turkey

${ }^{5}$ Gazi University Faculty of Medicine, Department of Cardiology, Ankara, Turkey

6 Ministry of Health, Ankara City Hospital, Clinic of Family Medicine, Ankara, Turkey
\end{abstract}

\begin{abstract}
Introduction: Cigarette smoking is one of the most important preventable risk factors for atherosclerotic diseases. This study aims to assess the smoking behaviour after acute coronary syndrome (ACS) and aims to delineate the factors affecting smoking status after discharge.

Methods: The Fagerström Test for Nicotine Dependence score, the sociodemographic status of patients, types of ACS and applied treatment methods were recorded. The Gensini scoring system was used to evaluate the extent and severity of coronary artery disease. Patients were reached via phone calls in the first, third and sixth month after discharge to assess their smoking status, their reasons for relapse and any recurrences of their diseases.
\end{abstract}

Results: Forty-five percent of patients were treated for STelevated myocardial infarction, and $43.2 \%(n=48)$ had high or very high levels of dependence. Patients who had early symptoms had a higher rate of quitting smoking $(p=0.009)$. Only $78.4 \%$ had thought of quitting smoking after discharge. Seventy-four (66.6\%) patients underwent catheter-based interventions. The rates of relapse were $20.8 \%(n=15), 42.6 \%$ $(n=32)$ and $53.9 \%(n=41)$ at the end of the first, third and sixth month after discharge, respectively. Gensini scores seemed to be higher among patients who had quit smoking $(p<0.05)$. Patients who have received medical treatment had a higher rate of smoking than before the end of six months $(p<0.05)$. Only 28.8\% ( $n=32)$ of patients stated that they had received information about smoking cessation from their family

\section{ÖZ}

Amaç: Sigara içmek aterosklerotik hastalıklar için önlenebilir en önemli risk faktörlerinden biridir. Bu çalışmada, akut koroner sendrom (AKS) sonrası sigara içme davranışı ile taburculuk sonrası sigara içme durumunu etkileyen faktörler değerlendirildi.

Yöntemler: Hastalara ait, Fagerström Nikotin Bağımlılığı testi skoru, hastaların sosyodemografik durumu, AKS tipleri ve uygulanan tedavi yöntemleri kaydedildi. Koroner arter hastalığının yaygınlığını ve şiddetini değerlendirmek için Gensini skorlama sistemi kullanıldı. Hastalara taburcu olduktan bir, üç ve altı ay sonra, sigara içme durumlarını, yeniden başlama nedenlerini, hastalıklarının nükslerini değerlendirmek için telefon görüşmeleri yoluyla ulaşıldı.

Bulgular: Hastaların \%45’i ST yükselmeli miyokard enfarktüsü nedeniyle tedavi edildi ve $\% 43,2$ 'sinde $(n=48)$ yüksek veya çok yüksek bağımlılık düzeyleri vardı. Erken semptomlarla başvuran hastaların sigarayı bırakma oranı daha yüksekti $(p=0,009)$. Sadece $\% 78,4^{\prime}$ ü taburcu olduktan sonra sigarayı bırakmayı düşünmüștü. Hastaların 74'üne $(\% 66,6)$ kateter bazlı girişim uygulandı. Sigara içmeye yeniden başlama oranları taburcu olduktan sonraki 1., 3. ve 6. ayların sonunda sırasıyla \%20,8 $(n=15), \% 42,6(n=32)$ ve $\% 53,9(n=41)$ idi. Gensini skoru, sigarayı bırakanlarda daha yüksek olma eğilimindeydi $(p>0,05)$. Medikal takip kararı verilen hastalarda 6. ayın sonunda sigara içme oranı daha yüksekti $(p<0,05)$. Hastaların sadece $\% 28,8 i(n=32)$ aile hekimlerinden sigara
Address for Correspondence/Yazıșma Adresi: Aybüke Demir Alsancak MD, Ministry of Health, Konya Provincial Health Directorate, Konya, Turkey

Phone: +90 5057502534 E-mail: demiraybuke@gmail.com ORCID ID: orcid.org/0000-0002-8433-2437

Cite this article as/Atıf: Demir Alsancak A, Sengezer T, Alsancak Y, Dincer G, Kızıltunç E, Özkara A. Short- and Mid-term Effects of Acute Coronary Syndromes on Smoking Behaviour, Factors Affecting Smoking Status and the Family Physicians' Role After Discharge. İstanbul Med J 2020; 21(6): 443-450.

(c) Copyright 2020 by the University of Health Sciences Turkey, Istanbul Training and Research Hospital/istanbul Medical Journal published by Galenos Publishing House.

(C) Telif Hakkı 2020 Sağlık Bilimleri Üniversitesi istanbul Ĕgitim ve Araştırma Hastanesi/Istanbul Tıp Dergisi, Galenos Yayınevi tarafından basılmıștır.
Received/Geliş Tarihi: 25.02.2020 Accepted/Kabul Tarihi: 27.09 .2020 
physician and $3.6 \%(n=4)$ of patients have applied to a smoking cessation unit.

Conclusion: Smoking cessation rates of patients who have suffered an ACS were low and rates of cigarette consumption in the following periods tended to increase. Family physicians should take a more active role in this topic in Turkey.

Keywords: Acute coronary syndrome, primary care, smoking smoking cessation, preventive cardiology bırakma hakkında bilgi aldığını ve \%3,6'sı (n=4) sigara bırakma polikliniğine bașvurduklarını belirtmiștir.

Sonuç: AKS geçiren hastaların sigara bırakma oranları düşüktür ve takip eden dönemlerde sigara tüketim oranları artma eğilimindedir. Türkiye'de, aile hekimleri bu konuda daha aktif rol almalıdır.

Anahtar Kelimeler: Akut koroner sendrom, birinci basamak, sigara, sigara bırakma, koruyucu kardiyoloji

\section{Introduction}

Due to the rise of industrialisation and the resulting increase in city populations, contagious diseases and nutritional disorders are being replaced by chronic conditions such as cardiovascular diseases and cancer. Despite advances in the treatment of cardiovascular diseases, they rank first among the causes of mortality according to the World Health Organization data $(1,2)$. Acute myocardial infarction (AMI) is an important problem of public health as it manifests during productive years, can result in sudden death and has variable complications. The most well-known cause of coronary artery disease is atherosclerosis (3). Atherosclerosis is considered a multifactorial disease in which every step involves chronic inflammation and each underlying factor contributes to the inflammatory process (4).

Cigarette smoking is one of the most important preventable risk factors for atherosclerotic diseases (5). With several effects, cigarette use leads to destabilisation of the atherosclerotic plaque and, therefore, acute coronary syndromes (ACS) (6). In patients who quit smoking before or after coronary interventions or coronary artery by-pass surgery, AMI and mortality rates are reportedly lower (7). However, during quitting cigarette smoking, several mental and physiological changes occur since smoking typically induces psychological and physical addiction (8-10). On days 1-3 after quitting smoking, withdrawal symptoms reach their peak and subside in the fourth week. For some people, they may linger for six months. It is of paramount importance to intervene at these time points to prevent relapse (11).

Our aim in this study is to assess how patients' smoking behaviour is affected when being discharged after coronary angiography for ACS and the factors that affect those who continue smoking after discharge. Another aim is to highlight the role of smoking cessation centres and family physicians that form the preventive medicine basis in this process, beginning with patients' hospitalisation for an ACS.

\section{Methods}

Our study was designed as a prospective and descriptive study. One hundred and eleven actively smoking patients who underwent coronary angiography for an ACS at the Ankara Numune Training and Research Hospital, Cardiology Clinic between June 2016 and August 2016, were included in the study. On admission, patients received questions about their sociodemographic features, disease conditions, risk factors, smoking behaviour and their levels of motivation for quitting smoking. The Fagerström Test for Nicotine Dependence (FTND) that consisted of six questions was utilised to quantify patients' cigarette addiction.
The scores of this test were classified into five groups: patients with a score of 0-2 were considered to have "very low", scores of 3-4 were "low", a score of 5 was "intermediate", scores of 6-7 were "high", scores of 8-10 were "very high" levels of dependence (12). The routine workup data, electrocardiographic findings, the history of interventions due to coronary artery disease, the number of days of hospitalisation per patient were noted. The Gensini scoring system was used to evaluate the extent and severity of coronary artery disease. This score was calculated by considering the level and the regional anatomic significance of the stenosis. This method defines a narrowing of the lumen of the coronary arteries as 1 for $1 \%$ to $25 \%$ stenosis, 2 for $26 \%$ to $50 \%$ stenosis, 4 for $51 \%$ to $75 \%$ stenosis, 8 for $76 \%$ to $90 \%$ stenosis, 16 for $91 \%$ to $99 \%$ stenosis and 32 for total occlusion. The score is then multiplied by a factor that represents the importance of the lesion's location in the coronary artery system. Those with Gensini scores over 20 were noted to have severe coronary artery disease, whereas those with scores of 20 or lower were noted to have mild-moderate coronary artery disease (13-15). There are several scoring systems to quantify the angiographic coronary artery disease burden. We preferred to evaluate the extensiveness of atherosclerosis with the Gensini score system because it is one of the most widely used systems according to the literature (15). Patients were reached via phone calls in the first, third and sixth month after discharge to assess their smoking status, their reasons for relapse, any recurrences of their diseases, whether they have received any advice for quitting and whether they had applied to a smoking cessation centre. The study received ethical review and approval from Ankara Numune Training and Research Hospital Local Ethics Committee with the decision number E-15/460 (date: 26.03.2015). Our study was consistent with the Declaration of Helsinki. Written consent was obtained from all participants.

\section{Statistical Analysis}

SPSS for Windows 18 package programme was used for the statistical analysis. Descriptive statistics were depicted as mean \pm standard deviation or median [interquartile range (IQR)] or minimum-maximum values for continuous variables, and as the number of cases (n) and percentages (\%) for categorical variables. The normality distribution was evaluated using the Kolmogorov-Smirnov test. Baseline characteristics were compared with the independent sample t-test, Mann-Whitney $U$ test, chi-square test or a One-Way analysis of variance (ANOVA). The mean values of continuous variables were compared between groups using the t-test, One-Way ANOVA test or Kruskal-Wallis test. The chi-square test was performed to compare the differences between 
categorical variables. An ANOVA was used for the analysis of parameters with multiple variables. A p-value of less than 0.05 was considered statistically significant.

\section{Results}

The study included 111 patients with a mean age of $53 \pm 9.8$ years, among which 105 (94.6\%) were males. First, it was found that 36\% of participants had a history of coronary artery disease, and $45 \%$ of the study population was treated with ST-elevated myocardial infarction. Also, we have shown that most patients lived in city centres (75.7\%), had at least a primary-school education (45.9\%) and most patients were in the low-middle income category (71.2\%). Of study patients, $63.1 \%$ $(n=70)$ thought smoking influenced their current ailment whereas $11.7 \%$ $(n=13)$ did not. Basic demographic features of the study population are summarised in Table 1. Regarding smoking behaviour, the mean smoking duration was $35.2 \pm 14.9$ pack-years, the mean cigarette consumption was $37 \pm 19.9$ cigarettes/day, and the FTND showed that $43.2 \%(n=48)$ of patients had high or very high levels of dependence. Tables 2 and 3 summarise the smoking history of the study population.

The most frequent complaint about admission to a hospital was chest pain $(77.5 \%, n=86)$, whereas $13.5 \%(n=15)$ were admitted with atypical symptoms. Fifty-eight patients (52.3\%) were admitted within an hour after the onset of their complaints. The mean duration of hospital stay was $2.3 \pm 1.59$ days. The mean ejection fraction after discharge from the hospital was $53 \% \pm 11 \%$. Twelve patients (10.8\%) had an ejection fraction of $35 \%$ or lower. The average Gensini score of patients was noted as $42.5 \pm 29.41 ; 75.6 \%(n=84)$ patients had a Gensini score higher than 20 (extensive coronary artery disease). Seventy-four (66.6\%) of patients underwent catheter-based interventions (balloon angioplasty, baremetal stent implantation, drug-eluting stent implantation), whereas $26.1 \%(n=29)$ received medical treatment and $7.2 \%(n=8)$ underwent coronary artery by-pass surgery.

\begin{tabular}{|l|l|}
\hline \multicolumn{2}{|l|}{ Table 1. Basal and characteristic features of the study population } \\
\hline Variable & $\mathbf{n}(\%)$ \\
\hline Diabetes mellitus & $24(21.6)$ \\
\hline Hypertension & $34(30.6)$ \\
\hline Hyperlipidaemia & $31(27.9)$ \\
\hline Family history & $63(56.8)$ \\
\hline Sedentary lifestyle & $78(70.3)$ \\
\hline Alcohol use & $23(20.7)$ \\
\hline Chronic obstructive pulmonary disease & $10(9)$ \\
\hline Peripheral artery disease & $6(5.4)$ \\
\hline Cerebrovascular disease & $5(4.5)$ \\
\hline Malignancy & $5(4.5)$ \\
\hline Marital status (married) & $91(82)$ \\
\hline The presence of coronary artery disease & $40(36)$ \\
\hline Previous acute coronary syndrome & $2(1.8)$ \\
\hline Diagnostic coronary angiography & $9(8.1)$ \\
\hline Stent implantation after coronary angiography & $19(17.1)$ \\
\hline By-pass surgery after coronary angiography & $7(6.3)$ \\
\hline Previous coronary artery by-pass surgery and stent & $3(2.7)$ \\
\hline
\end{tabular}

At the end of six months, the rate of visiting a family physician for any reason was $48.6 \%(n=54) ; 59.3 \%(n=32)$ received information from their family physician on smoking cessation. The optimistic thoughts of patients on the effectiveness of this information given at the first, third and sixth month gradually ceded. At six months, $40.7 \%$ of patients had positive thoughts about smoking cessation information ( $p=0.043)$. A small group of patients $(3.6 \%, n=4)$ had applied to a smoking cessation unit by the sixth month after discharge. Table 3 summarises patients' smoking status after discharge. The rates of re-starting smoking are also shown in Figure 1.

\section{Table 2. Smoking behaviour of the study population} Variable $\%$

Daily cigarette consumption

10 cigarettes or less 9.9

Between 11-20 cigarettes

21 cigarettes or more

Age at which smoking commenced

15 years and under 37.8

16 years and over

Having tried smoking cessation at any time

Longest duration of smoking cessation

(months, mean $\pm \mathrm{SD}$ )

Having joined a smoking cessation programme

Psychological support

8.1

Nicotine replacement therapy

Drug therapy

Personal attempt

Smoking status of family members

Spouse

Parent

Children

Siblings

Smoking place of family members

Inside the house

Outside the house/balcony

Thoughts of quitting smoking after discharge from the hospital

Knowledge about smoking cessation centre

Postdischarge thoughts of getting help from a smoking cessation centre

Fagerström nicotine dependence test

Very low level

Low level

Intermediate level

High level

Very high level

Number of patients that claim to have quit smoking at the time of discharge 
The comparison of the clinical and demographic features of smoking and non-smoking patients at the end of the sixth month after discharge is shown in Table 4. We found that there was no statistically significant difference between patients who quit smoking and those that did not in terms of age, gender, mean monthly income, occupation, antidepressant use, the presence of known risk factors for coronary artery disease (diabetes mellitus, hypertension, hyperlipidaemia, positive family history) and the presence of any combinations of these risk factors at the time of discharge $(p>0.05)$. In addition, in the first and third months, the level of education $(p=0.001)$ and the ratio of patients who had an ST-elevated myocardial infarction $(p=0.001)$ were higher among those that quit smoking than those that did not. At the end of six months, these distributions were similar among smokers and patients who had quit smoking. Those that applied with early symptoms had a higher rate of quitting smoking at all three time points $(p=0.009)$. Likewise, those that quit smoking by the end of the first or the third month after their discharge from the hospital had a longer non-hospitalised period ( $p=0.001$ ). However, by the end of the sixth month, a period of non-hospitalisation was similar in both groups $(p=0.169)$. Thoughts of smoking were more prevalent among patients who quit smoking at all time points than those who continued to smoke $(p<0.001)$. Attempts at quitting were also more frequent among these patients in the first three months $(p=0.014)$, but this association lost statistical significance in the sixth month $(p=0.855)$. Patients who had a long history of smoking had a higher rate of quitting by the end of the first and third months

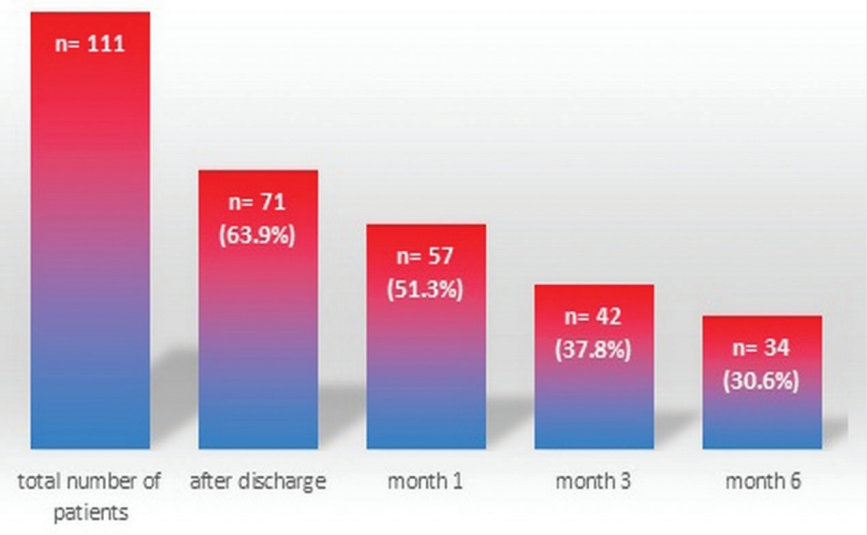

Figure 1. The number of patients who quit smoking after discharge

Table 3. Smoking behaviour of the study population after hospitalisation

\begin{tabular}{l} 
Variable \\
\hline Number of patients that applied to a smoking cessation centre after discharge \\
\hline Psychological support \\
\hline NRT \\
\hline Drug therapy
\end{tabular}

Month 1 after discharge (\%)

1.8

0.9

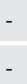

100

Reason for re-starting smoking

\begin{tabular}{|l|}
\hline Wish to smoke \\
\hline Stressful event \\
\hline Rough familial situation \\
\hline Due to being fired \\
\hline Influenced by family members \\
\hline Total amount of time spent without smoking \\
\hline Never quit \\
\hline$<1$ month \\
\hline $1-3$ months \\
\hline $3-6$ months \\
\hline Did not smoke for 6 months \\
\hline
\end{tabular}

Number of cigarettes/day for those that kept smoking

10 or less

Between 10 and 20

Between 21 and 30

31 or more

Smoking status of family members

Inside the house

Outside of house/balcony

Re-hospitalisation after discharge for an ACS

ACS: Acute Coronary syndrome, NRT: nicotine replacement therapy

\begin{tabular}{|l|l|}
\hline $\begin{array}{l}\text { Month 3 after discharge } \\
(\%)\end{array}$ & $\begin{array}{l}\text { Month } \mathbf{6} \text { after } \\
\text { discharge (\%) }\end{array}$ \\
\hline 1.8 & 3.6 \\
\hline 0.9 & 1.8 \\
\hline- & - \\
\hline 0.9 & 1.8 \\
\hline 50 & 25 \\
\hline & \\
\hline 50 & 41.4 \\
\hline 31.2 & 29.2 \\
\hline 15.6 & 24.3 \\
\hline 3.1 & 2.4 \\
\hline- & 2.4 \\
\hline & 32.4 \\
\hline- & 21.6 \\
\hline- & 10.8 \\
\hline- & 6.3 \\
\hline- & 28.8 \\
\hline- & 44.1 \\
\hline 43.4 & 49.3 \\
\hline 52.1 & 3.8 \\
\hline 1.4 & 2.5 \\
\hline 2.8 & 38.7 \\
\hline 41.4 & 34.8 \\
\hline 39.1 & 65.2 \\
\hline 60.9 & 10.8 \\
\hline 1.8 & \\
\hline & \\
\hline
\end{tabular}


Table 4. Comparison of the clinical and demographic features of smoking and non-smoking patients at the end of six months

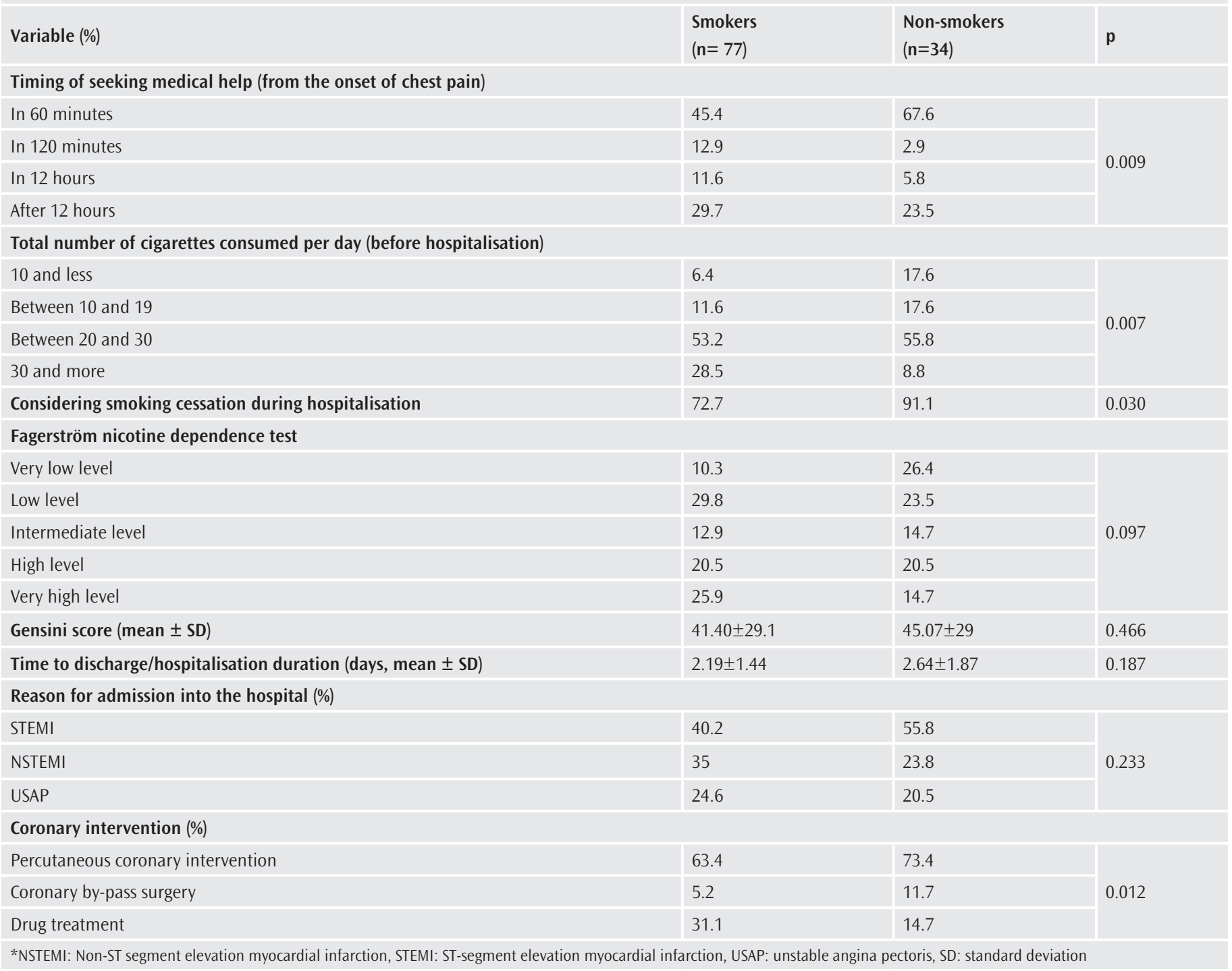

( $p=0.026)$, whereas at the end of six months, rates were similar $(p=0.067)$. Also, patients with chronic obstructive pulmonary disease (COPD) had a higher smoking rate after six months $(p=0.001)$. Although smoking rates among marital status and occupational groups were statistically similar in the first three months, by the end of six months, rates of re-starting smoking were higher among singles and widows $(p=0.036)$ and actively working civil servants and workers $(p=0.048)$. We did not find an effect on patients' primary complaint on smoking cessation $(p=0.450)$.

\section{Discussion}

The present study demonstrates that an important fraction of patients who suffer from an ACS start smoking again during the short-term follow-up after discharge for various reasons. Furthermore, our study is noteworthy for showing how family physicians, usually the cornerstone of preventive medicine, have a minor influence on encouraging and helping smoking cessation in this group of patients.
Cigarette smoking remains an important public health problem both in our country and worldwide. It has been reported in previous studies to increase disease risk for all cardiovascular conditions, such as ischaemic stroke, peripheral artery disease, aortic aneurysm and cardiac vascular disease (16-19). The cardiovascular risk abates rapidly after smoking cessation and, in 10-15 years, almost reaches that of a person that has never smoked (20-23). Hence, for people with diagnoses of coronary artery disease, or those that go through an episode of an ACS, smoking cessation is just as necessary as the proper implementation of medical treatment to lower morbidity and mortality. Several factors have been revealed that are involved in smoking initiation or cessation. A previously published study has demonstrated that there was no significant association between smoking cessation and age, education level or the presence of a smoker among core family members. However, male gender and being married had positive predictive value (24). Despite the wide range of distribution over gender, our study shows that gender does not have a significant association with smoking cessation $(p=0.92)$. 
Another important result of our study is that in the early stages, marital status does not have a significant effect on smoking cessation. However, at the end of six months, single or widowed patients had a higher rate of re-starting smoking. Previous studies have shown that increased cardiovascular mortality in widows in a year after the passing of a spouse was a considerable sign of psychosocial stress (25). These points to the significance of family support for cases of ACS, and a similar conclusion can also be reached from our data despite the relatively low number of subjects (26). As the most paramount and continuous source of motivation and support is the family itself, the behaviour and attitude of family members can be thought to act as an effective means of protection from cardiovascular diseases. In addition, our study has demonstrated that education level may influence smoking cessation behaviour at the time of discharge. However, at the first, third and sixth month, it has no predictive role in smoking cessation.

Another interesting finding made by the present study also found a lack of association between early stage smoking cessation behaviour and the presence of additional disease conditions (cerebrovascular events, peripheral artery disease, COPD and other conditions). Another striking result was a statistically significant tendency of COPD patients to keep smoking during the first, third and sixth month after discharge. A similar study conducted in ACS patients similarly mentions that patients with cigarette-related lung diseases tended to keep smoking at the three month-follow-up (27). It may be inferred that ACS itself may not have an impact big enough to quit smoking in patients with a prior diagnosis of cardiovascular disease and COPD. On the other hand, occupational groups that do not seem to influence smoking cessation behaviour at the time of discharge and early stages after discharge tend to gain importance at the sixth-month follow-up as those who actively work at the time they are influenced regarding their smoking behaviour. This finding may indicate that smoking behaviour is affected dramatically by the social environment.

Another topic of discussion arises from the finding that symptoms at the time of applying for hospital admission in patients with ACS have no role in smoking cessation behaviour at either early or late stages of followup. Patients who seek medical help soon after the onset of symptoms tended to have higher rates of smoking cessation at the time of discharge. However, this association gradually lost statistical significance at the end of six months post-discharge. This result indicates a time-dependent loss of the deterrent effect of symptoms experienced during the early phases. On the other hand, patients who seek help early may have better selfcare in general, and those who were admitted later may be relatively more negligent of their health issues in their daily lives. This difference might contribute to the lack of smoking cessation behaviour. Physicians may help these patients by delivering reminders during follow-ups in a manner that will not induce psychological trauma while considering the possibility of developing post-traumatic stress disorder. In addition, at the time of discharge and in the first and third months, smoking cessation rates were higher in patients with ST-elevated myocardial infarction, which presents as a more urgent clinical event. However, at the end of six months, no statistically significant difference was detected among the groups. This may, as was pointed out above, reflect the lack of constraint for continuing their daily lives after discharge from the hospital. Re-starting smoking, while normalising daily life functions, especially for those who are actively working post-discharge, may have accounted for this result. In our study, Gensini scores that express the severity of coronary artery disease and higher numbers of stents did not display a statistically significant relationship with smoking cessation behaviour.

Despite including occlusion percentages in a manner that can be comprehended, angiography reports given to patients after angiography did not have a substantial effect on smoking cessation. It may be inferred that not only visual, but verbal suggestions that include detailed information can yield a stronger influence for smoking cessation during the early stages. The advice and warnings given by the cardiologist that intervene first can have the most substantial influence in the early stages. It was demonstrated that $77.2 \%$ of family physicians question the smoking/tobacco use status of their patients, yet only $25.6 \%$ of them and $8.4 \%$ of nurses provide advice about smoking cessation (28). Our study shows the rate of receiving advice from the health centre that rendered the first diagnosis, including family physicians, was $77.5 \%$. Although this rate seems high, the fact that not all patients receive simple smoking-related advice is a deficit of paramount importance. It can be considered a lack of attention on the physician's part that the number of patients referred to a smoking cessation centre is low $(3.6 \%$ at the end of six months). Özșahin et al. (29) have stated that the two most important factors in quitting smoking are health problems and anti-smoking media campaigns. The same study showed that the third most important reason to quit smoking was physician advice. More attention on the part of physicians can yield more poignant results, along with effectively adding smoking cessation as primary protection into physician education programmes.

In addition to the data described above, patients who had duration of hospitalisation and those that underwent interventional treatments had more significant quitting behaviour during the first three time periods. However, this difference diminished at the end of the sixth month. This reduction may be explained by the condition at presentation, the psychologic status of the patient after an interventional procedure and the exposure to other patients with more severe conditions during their stay in intensive care units. Another point that warrants attention is the lower than expected rate of family physician visits during the sixmonth period. These rates are $15.3 \%, 45 \%$ and $48.6 \%$ at the end of the first, third and sixth month, respectively. The ratios of patients stating that they have received smoking cessation advice from their family physicians during these visits are 58.8\%, 58\% and 59.3\%, respectively. Almost one of two physicians made no suggestions about quitting smoking. The role of family physicians is very important in smoking cessation counselling. This data may demonstrate that in the primary care setting where preventive medicine has its basis, this subject is not adequately addressed. We may say that family physicians are not properly involved in the fight against tobacco smoking in our country. The lack of data on why patients visited their family physicians can be counted as a limitation of the present study. It may be more effective for relevant institutions to send patients directly to the family physicians after ACS so that the doctor-patient relationship can be formed earlier. 
For this reason, educational and training programmes on the fight against smoking should be organised for family physicians. It was shown that patients who implemented lifestyle changes had a significant increase in both physical and mental components of life quality (30). The rates of explaining lifestyle changes to patients by physicians were low in our study, despite the vital importance of such advice. Although it may not be easy to assess a behavioural change for smoking in a short time after ACS, our results demonstrated that there is inadequate patient compliance, and there are deficiencies in the family physicianpatient relationship.

Both physicians and other healthcare staff are informed about the harmful effects of smoking and smoking cessation methods. However, not only the amount of information but attitude gains importance at this point. The most significant attitude on this subject is being a "role model". When considering how physicians and other healthcare workers can act as role examples, it is of paramount importance that they do not smoke (28). Furthermore, the first step in the fight against tobacco dependence is a "brief physician intervention" that is described as "the verbal summarisation of the indications of smoking cessation using medical terms and information about the harmful effects of smoking". These are short communications that can be used by all physicians in any setting (31). Especially in clinics that are interested in illness due to smoking like cardiology, teams of the medical staff that reach hospitalised patients and deliver "short motivational visits" can yield more favourable results.

\section{Conclusion}

In conclusion, the smoking cessation rate of patients who suffered an ACS is low, and rates of cigarette consumption during the periods that follow tend to soar. A multidisciplinary cooperative effort involving all physicians, especially family physicians and cardiologists, is required at times when patients attempt quitting smoking or start smoking again. In addition, it should be considered that family physicians in Turkey need to take a more active role in this regard.

\section{Ethics}

Ethics Committee Approval: The study received ethical review and approval from Ankara Numune Training and Research Hospital Local Ethics Committee (decision no: E-15/460, date: 26.03.2015).

Informed Consent: Written consent was obtained from all participants.

Peer-review: Externally and internally peer-reviewed.

Authorship Contributions: Concept - A.D.A., T.S., Y.A., G.D., A.Ö.; Design - A.D.A., T.Ş., Y.A., G.D., E.K.; Data Collection or Processing - A.D.A., E.K.; Analysis or Interpretation - A.D.A., T.Ş., G.D., E.K., A.Ö.; Literature Search - A.D.A., T.S., Y.A., G.D., A.Ö.; Writing - A.D.A., T.Ş., G.D.

Conflict of Interest: No conflict of interest was declared by the authors.

Financial Disclosure: The authors declared that this study received no financial support.

\section{References}

1. Murray CJ, Lopez AD. Global mortality, disability, and the contribution of risk factors: Global Burden of Disease Study. Lancet 1997; 349: 1436-42.
2. Guilbert JJ. The world health report 2002 - reducing risks, promoting healthy life. Educ Health (Abingdon) 2003; 16: 230.

3. Mallika V, Goswami B, Rajappa M. Atherosclerosis pathophysiology and the role of novel risk factors: a clinicobiochemical perspective. Angiology 2007; 58: 513-22.

4. Kumar V, Burns DK. Hearth. In: Kumar V, Cotran RS, Robbins SL, editors. Basic Pathology. Philadelphia: WBSC; 2003.p.361-94.

5. Schroeder SA. New evidence that cigarette smoking remains the most important health hazard. N Engl J Med 2013; 368: 389-90.

6. Ambrose JA, Barua RS. The pathophysiology of cigarette smoking and cardiovascular disease: an update. J Am Coll Cardiol 2004; 43: 1731-7.

7. Sugiishi M, Takatsu F. Cigarette Smoking Is Risk Factor for Coronary Spasm. Circulation 1993; 87: 76-9.

8. Dilektașli AG. Pharmacological Treatment for Smoking Cessation. Turkiye Klinikleri Journal Pulm Med-Special Topics 2012; 5: 43-50.

9. Breslau N, Kilbey MM, Andreski P. Nicotine withdrawal symptoms and psychiatric disorders: findings from an epidemiologic study of young adults. Am J Psychiatr 1992; 149: 464-9.

10. Acri JB, Grunberg NE. A psychophysical task to quantify smoking cessationinduced irritability: the reactive irritability scale (RIS). Addict Behav 1992; 17: 587-601.

11. Sönmez Cl, Özbey Z. Neurbiology and Clinical Features of Nicotine Dependence. Turkiye Klinikleri J Fam Med-Special Topics 2016; 7: 13-9.

12. Demir T. Smoking Cessation. In: Ugur M, Balcioglu I, Kocabasoglu N, editors. Common Psychiatric Disorders in Turkey. İstanbul: IU Cerrahpasa Medical Faculty Continuing Medical Education Activities; 2008.p.231-8.

13. Gensini GG. Coronary arteriography: role in myocardial revascularization. Postgrad Med 1978; 63: 121-38.

14. Gensini GG. A more meaningful scoring system for determining the severity of coronary heart disease. Am J Cardiol 1983; 51: 606.

15. Neeland IJ, Patel RS, Eshtehardi P, Dhawan S, McDaniel MC, Rab ST, et al. Coronary angiographic scoring systems: an evaluation of their equivalence and validity. Am Heart J 2012; 164: 547-52.

16. World Health Organization. Diet, nutrition and the prevention of chronic diseases: report of a Joint WHO/FAO Expert Consultation. Geneva, Switzerland. 2002. WHO technical report series 916.

17. Edwards R. The problem of tobacco smoking. BMJ 2004; 328: 217-9.

18. Prescott E, Hippe M, Schnohr P, Hein HO, Vestbo J. Smoking and risk of myocardial infarction in women and men: longitudinal population study. BMJ 1998; 316: 1043-7.

19. Piepoli MF, Hoes AW, Agewall S, Albus C, Brotons C, Catapano AL, et al. 2016 European Guidelines on cardiovascular disease prevention in clinical practice: The Sixth Joint Task Force of the European Society of Cardiology and Other Societies on Cardiovascular Disease Prevention in Clinical Practice (constituted by representatives of 10 societies and by invited experts) Developed with the special contribution of the European Association for Cardiovascular Prevention \& Rehabilitation (EACPR). Atherosclerosis. 2016; 252: 207-74.

20. World Health Organization. IARC handbooks of cancer prevention. Volume 10. Cervix cancer screening. Lyon, France; IARCPress: 2005.

21. Critchley JA, Capewell S. Smoking cessation for the secondary prevention of coronary heart disease. Cochrane Database Syst Rev 2004: CD003041.

22. Chow CK, Jolly S, Rao-Melacini P, Fox KA, Anand SS, Yusuf S. Association of diet, exercise, and smoking modification with risk of early cardiovascular events after acute coronary syndromes. Circulation 2010; 121: 750-8. 
23. Anthonisen NR, Skeans MA, Wise RA, Manfreda J, Kanner RE, Connett JE, et al. The effects of a smoking cessation intervention on 14.5-year mortality randomized clinical trial. Ann Intern Med 2005; 142: 233-9.

24. Rice VH, Templin T, Fox DH, Jarosz P, Mullin M, Seiggreen M, et al. Social context variables as predictors of smoking cessation. Tob Control 1996; 5 : 280-5.

25. Rees WD, Lutkins SG. Mortality of bereavement. BMJ 1967; 4: 13-6.

26. Altunbaş G, Aksoy M. The importance of family support in patients with acute coronary syndromes from diagnosis to therapy. Turk Kardiyol Dern Ars 2015; 43: 15-7.

27. Attebring MF, Hartford M, Hjalmarson A, Caidahl K, Karlsson T, Herlitz J. Smoking habits and predictors of continued smoking in patients with acute coronary syndromes. J Adv Nurs 2004; 46: 614-23.
28. Sonmez Cl, Aydin LY, Turker Y, Baltaci D, Dikici S, Sariguzel YC, et al. Comparison of smoking habits, knowledge, attitudes and tobacco control interventions between primary care physicians and nurses. Tob Induc Dis 2015; 13: 37.

29. Özşahin K, Ünsal A, Erdoğan F, Gereklioğlu Ç, Bakar C, Tokalak İ. Factors Effective on Smoking Cessation: A Study On Family Practice Patients. TAF Prev Med Bull 2007; 6: 181-6.

30. Babaee G, Keshavarz M, Hidarnia A, Shayegan M. Effect of a health education program on quality of life in patients undergoing coronary artery bypass surgery. Acta Med Iran 2007; 45: 69-75.

31. Eray IK. Brief Clinician Advice in Tobacco Addiction and 5A-5R Approach. Turkiye Klinikleri J Fam Med-Special Topics 2016; 7: 39-43. 